\title{
PENGARUH PEMBERIAN EKSTRAK GARCINIA MANGOSTANA TERHADAP KADAR GULA DARAH PADA PENDERITA DIABETES MELLITUS DI DESA SATREAN MARON PROBOLINGGO
}

\author{
Nurul Laili ${ }^{1)}$, Roi'sah ${ }^{2)}$, Nafolion Nur Rahmat ${ }^{3)}$ \\ Program Studi Sarjana Keperawatan StiKes Hafshawaty Pesantren Zainul Hasan \\ email: nurul_yaqiniku@yahoo.com
}

\begin{abstract}
Abstrak
Penyakit diabetes mellitus merupakan salah satu penyakit penyakit tidak menular (PTM) yang membutuhkan penannganan tepat untuk proses penyembuhan. Penyakit tersebut jika tidak diobati akan menyebabkan timbulnya komplikasi yang dapat membahayakan penderita. Cara yang dilakukan untuk mencegah timbulnya komplikasi adalah melalui pengobatan. Salah satu jenis pengobatan yang digunakan adalah pengobatan herbal yaitu Garcinia Mangostana. Tujuan penelitian ini adalah untuk mengetahui pengaruh pemberian ekstrak Garcinia Mangostana terhadap kadar gula darah penderita diabetes mellitus. Metode penelitian ini menggunakan quasy-experiment dengan desain pre-test and post-test with control group. Pengambilan sampel menggunakan simple random sampling, berdasarkan rumus perhitungan sampel, maka diperoleh sampel sebanyak 36 penderita diabetes mellitus. Instrumen yang digunakan dalam penelitian ini berupa alat cek gula darah untuk mengukur kadar gula darah sewaktu. Uji statistic "paired TTest" menggunakan media komputer program "Windows SPSS 17”. Data pengukuran berupa data rasio yaitu nilai kadar gula darah sewaktu dalam $\mathrm{mg} / \mathrm{dl}$. Hasil analisa data menunjukkan pada kelompok perlakuan memiliki nilai $p=0,001$, hal tersebut berarti ada pengaruh pemberian kulit manggis terhadap kadar gula darah, sedangkan pada kelompok kontrol memiliki nila $p=0,166$. Sehingga dapat disimpulkan bahwa Garcinia Mangostana efektif dalam menurunkan kadar gula darah pada penderita diabetes mellitus.
\end{abstract}

Kata kunci: diabetes mellitus, garcinia mangostana, kadar gula, penderita.

\begin{abstract}
Diabetes mellitus is one of the non-communicable diseases (PTM diseases) that requires proper response to the healing process. The disease if left untreated will cause complications that can endanger the patient. The way to prevent complications is through treatment. One type of treatment used is herbal medicine, Garcinia Mangostana. The purpose of this study was to determine the effect of giving Garcinia Mangostana extract to blood sugar levels of people with diabetes mellitus. This research method used quasyexperiment with the design of pre-test and post-test with control group. Sampling using simple random sampling, based on the sampel calculation formula, obtained sampels of 36 people with diabetes mellitus. The instrument used in this study is a blood sugar check tool to measure blood sugar. Test the "paired TTest" statistic using the computer media program "Windows SPSS 17". Measurement data in the form of ratio data, namely the value of blood sugar levels when in $\mathrm{mg} / \mathrm{dl}$. The results showed that there was an effect of giving mangosteen peel to blood sugar levels in patients with diabetes mellitus with a value of $p=0.001$.
\end{abstract}

Keywords: diabetes mellitus, garcinia mangostana, sugar levels, patients 


\section{PENDAHULUAN}

Diabetes Melitus merupakan salah satu penyakit metabolisme yang ditandai dengan meningkatnya kadar gula glukosa (gula darah) di dalam tubuh seseorang yang melebihi batas normal (Marewa, 2015). Berdasarkan World Health Organization (WHO) menunjukkan bahwa prevalensi penderita diabetes mellitus di Indonesia memiliki potensi mengalami kenaikan secara drastis dari 8,4 juta penderita pada tahun 2000 menjadi 21,3 juta penderita di tahun 2030 mendatang dan Indonesia sekarang ini menduduki peringkat ke-5 di wilayah Asia Tenggara (WHO, 2017). Angka penderita diabetes mellitus di Jawa Timur terus mengalami peningkatan yaitu, 605.974 orang $(2.1 \%)$. Di Probolinggo jumlah penderita DM dari tahun 2015 ke tahun 2016 yaitu sebanyak 3,539 menjadi 3.622 penderita (Dinas Kesehatan, 2016).

Hasil studi pendahuluan di Desa Satrean kecamatan didapatkan pada tahun 2018 sebanyak 40 warga yang menderita diabetes melitus. Hasil wawancara dengan 5 warga yang menderita diabetes mellitus, mengatakan belum pernah menggunakan kulit mamggis untuk menurunkan kadar gula darah. Warga yang menderita diabetes melitus hanya meminum obat dari bidan atau dokter. Diabetes Mellitus dapat menyebabkan komplikasi jika tidak mendapat penanganan yang tepat, komplikasi tersebut antara lain komplikasi akut (mendadak) dan komplikasi kronis (menahun) (Sri Hartini, 2009). Penanganan penyakit Diabetes Mellitus dapat dilakukan dengan cara memberikan terapi obat sintetis dan obat herbal (Adika, 2013). Pemberian terapi obat sintetis seperti obatobatan hipoglikemik oral (OHO), dan insulin. Pemberian terapi obat herbal seperti obat yang berasal dari tumbuh-tumbuhan yang ada di sekitar masyarakat dapat di manfaatkan untuk obat herbal penderita DM (Riyadi Sujono, 2008).

Terapi obat sintetis yang diberikan untuk mengatasi penyakit diabetes mellitus, selain harganya yang mahal, terapi obat sintetis juga dapat memberikan efek samping yang cukup berbahaya bagi fungsi tubuh. Gejala-gejala yang ditimbulkan dari efek samping tersebut adalah pusing, keringat dingin, gelisah, bingung, sulit berbicara bahkan tidak sadarkan diri (Sarmoko, 2018). Masyarakat saat ini lebih memilih memanfaatkan obat herbal karena memiliki banyak keuntungan yaitu mudah didapat, harganya terjangkau dan alasan yang paling penting tidak menimbulkan efek samping yang berbahaya bagi tubuh (Manukumar et al. 2017).

Salah satu jenis terapi obat herbal yang dikembangkan saat ini adalah Garcinia Mangostana. Buah manggis (Garcinia Mangostana) merupakan salah satu jenis tanaman herbal yang dipercaya dapat membantu menurunkan kadar gula darah penderita diabetes mellitus karena didalamnya terdapat kandungan atau zat seperti xanthone yang berperan mengurangi resistensi insulin sehingga mampu menormalkan kadar gula darah dalam tubuh dan mampu mengatasi kelelahan yang diakibatkan oleh kadar gula yang tidak seimbang (Umar, 2015). Tujuan penelitian ini adalah untuk mengetahui Pengaruh Pemberian Garcinia Mangostana terhadap Kadar Gula Darah pada Pasien Diabetes Mellitus di Kecamatan Maron Kabupaten Probolinggo.

\section{METODE PENELITIAN}

Penelitian ini menggunakan metode quasi eksperimen merupakan salah jenis penelitian eksperimen yang memanipulasi variabel independen, pemilihan subjek dilakukan secara random dan memiliki kelompok kontrol atau kelompok pembanding dengan menggunakan pre-test and post-test with control group design. Sampel yang digunakan dalam penelitian ini adalah diambil 36 responden yang terbagi menjadi 18 responden sebagai kelompok kontrol dan 18 responden sebagai kelompok perlakuan. Instrumen yang digunakan yaitu alat pengukur kadar gula darah sewaktu. Data hasil pengukuran berupa data rasio (nilai kadar gula darah sewaktu dalam satuan $\mathrm{mg} / \mathrm{dl}$ ). Intervensi yang diberikan dalam penelitian ini adalah pemberian konsumsi kulit manggis (Garcinia Mangostana) sebanyak 25-50 gr (2 buah kulit manggis ukuran kecil), kulit manggis (Garcinia Mangostana) dicuci terlebih dahulu, setelah itu direbus dengan 3 gelas air, hingga menjadi 1 gelas air, rebusan kulit manggis (Garcinia Mangostana) diminum 1 gelas perhari.

\section{HASIL DAN PEMBAHASAN}

Berikut ini adalah hasil penelitian pengaruh pemberian Garcinia Mangostana terhadap kadar gula darah pada penderita diabetes mellitus di desa Satrean kecamatan Maron kabupaten Probolinggo. 
Tabel 1. Distribusi a Responden Berdasarkan Usia, Jenis Kelamin, Lama menderita DM, Pekerjaan di Kecamatan Maron Kabupaten Probolinggo

\begin{tabular}{llcc}
\hline \multirow{2}{*}{$\begin{array}{l}\text { Variabel } \\
\text { Karakteristik }\end{array}$} & \multicolumn{2}{l}{ Kelompok Intervensi dan Kontrol } \\
\cline { 2 - 4 } & Kategori & Frekuensi & $\begin{array}{c}\text { Persen } \\
(\%)\end{array}$ \\
\hline Usia & 40-50 tahun & 8 & $22 \%$ \\
& $51-60$ tahun & 20 & $56 \%$ \\
& 61-70 tahun & 8 & $22 \%$ \\
Jenis & Laki-laki & 15 & $42 \%$ \\
Kelamin & Perempuan & 21 & $58 \%$ \\
Lama & 1-2 tahun & 13 & $36 \%$ \\
Menderita & $3-4$ tahun & 23 & $64 \%$ \\
DM & & & \\
Pekerjaan & Tidak & 3 & $8 \%$ \\
& bekerja & & \\
& Petani/ & 18 & $50 \%$ \\
& buruh & & \\
& Wiraswasta & 6 & $17 \%$ \\
& Swasta & 5 & $14 \%$ \\
& PNS & 4 & $11 \%$ \\
\hline
\end{tabular}

Berdasarkan hasil pengelompokan data karakteristik responden menunjukkan bahwa rata-rata usia responden yang menderita diabetes mellitus yaitu usia 51-60 tahun sebanyak 20 responden (56\%). Jenis Kelamin responden yang lebih banyak menderitan diabetese mellitus adalah perempuan sebanyak 21 responden $(58 \%)$. Lama waktu menderita penyakit dabetes mellitus rata-rata 3-4 tahun sebanyak 23 responden (64\%). Sedangkan untuk pekerjaan rata-rata responden bekerja sebagai petani/buruh sebanyak 18 responden $(50 \%)$.

Tabel 2. Pengaruh Pemberian Garcinia Mangostana terhadap Kadar Gula Darah pada Penderita Diabetes Mellitus di Desa Satrean Kecamatan Maron Kabupaten Probolinggo $(\mathrm{n}=36)$.

\begin{tabular}{lccc}
\hline \multicolumn{1}{c}{ Variabel } & Mean & T & $p$ \\
\hline $\begin{array}{l}\text { Kelompok } \\
\text { Pemberian } \\
\text { Garcinia }\end{array}$ & & & \\
Mangostana & & & \\
Pre test & 260.33 & 4.129 & 0.001 \\
Post test & 251.83 & & \\
Kelompok & & & \\
Kontrol & & & \\
Pre test & 264.28 & 1.448 & 0.166 \\
Post test & 262.44 & & \\
\hline
\end{tabular}

Berdasarkan hasil uji dengan Paired $T$ test dengan signifikansi $5 \%(0,05)$ diperoleh nilai $\mathrm{p}$ sebesar 0,001 , hal tersebut menunjukkan bahwa Ha diterima dan Ho ditolak dan berarti ada pengaruh konsumsi kulit manggis terhadap penurunan kadar gula darah pada penelitian ini.

Kadar gula darah responden memiliki rata-rata $251.83 \mathrm{mg} / \mathrm{dL}$ setelah diberi terapi konvensional berupa kulit manggis. Hasil tersebut menunjukkan bahwa terjadi penurunan nilai rata-rata gula darah responden dibandingkan dengan nilai rata-rata gula darah sebelum diberi kulit manggis yaitu 260.33 $\mathrm{mg} / \mathrm{dL}$. Kulit manggis memiliki berbagai manfaat terutama mampu menurunkan kadar gula darah. Kulit manggis mengandung zat yang bernama xanthone, antosianin yang berfungsi sebagai antioksidan dan antidiabetes sehingga mampu menurunkan kadar gula darah (Yunitasari, 2011). Kulit manggis mengandung lebih dari $90 \%$ xanthone (campuran alfa mangostin $80-90 \%$ dan gama mangostin 5$10 \%)$. Kerja insulin alfa glukosidase di dalam saluran cerna akan dihambat oleh Alfa mangostin sehingga dapat menurunkan hiperglikemia post prandial (Riyadi dkk, 2008). Proses penurunan kadar gula darah dilakukan dengan menurunkan hambatan dalam proses pembentukan insulin. Senyawa yang paling berperan dalam hal ini adalah mangiferin yang merupakan salah satu jenis senyawa xanthone (Warisno, 2012).

Kulit manggis sebagai sumber kaya akan inhibitor a-glukosidase yang kuat. Kulit manggis mampu membantu menurunkan glukosa postparndial (Ryu et al. 2011). Kulit manggis memiliki efek yang menguntungkan dalam proses penyembuhan penyakit akut dan penyakit kronis salah satunya penyakit diabetes, karena kandungan xanthone di dalam kulit manggis (Pedraza-Chaverri et al. 2008 \& Fatmawati et al. 2015). Pengobatan menggunakan kulit manggis mampu memperbaiki kadar gula darah, glikogen hati, profil lipid dan oksidatif stres (Karim et al. 2018).

Hasil penelitian tersebut sesuai dengan hasil penelitian lain yang menunjukkan bahwa ada pengaruh pemberian ekstrak kulit manggis terhadap kadar gula darah sewaktu responden yang menderita diabetess mellitus dengan nilai signifikansi yaitu $\mathrm{p}=0,001$ (Herminto et al., 2014). Selain itu terdapat penelitian lain yang menunjukkan hasil bahwa ekstrak kulit manggis mengandung metanol yang memiliki potensi terhadap kadar glukosa yang tinggi dengan hasil 
yang signifikan yaitu $\mathrm{p}=0,000$ (Khotimah et al., 2011). Penelitian yang lain menunjukkan bahwa kandungan zat kimia dalam kulit manggis (Garcinia Mangostana) yaitu xanton yang mampu menurukan kadar gula darah pada 7 pasien penderita diabetes mellitus (Eddy Yatman, 2012). Pemberian Ekstrak kulit manggis (Garcinia Mangostana) memberikan efek yang besar terhadap penurunan kadar gula darah dibandingkan dengan pemberian akuades. Ekstrak kulit manggiss (Garcinia Mangostana) memiliki efek antihiperglikemia yang efeknya tidak berbeda dengan glibenklamid (Sondang Manurung, dkk; 2013).

\section{KESIMPULAN DAN SARAN}

Berdasarkan penjelasan di atas dapat disimpulkan bahwa terdapat pengaruh pemberian kulit manggis responden yang memiliki penyakit diabetes mellitus di desa satreyan, Maron, Probolinggo. Kulit manggis memiliki fungsi sebagai antidiabetes karena tedapat kandungan xanthone, metanol dan alfa magostin di dalamnya, sehingga mampu menurunkan kadar gula darah pada penderita diabetes mellitus. Penelitian ini masih memiliki keterbatasan perlakuan dilakukan selama 1 bulan, dan pengukuran kadar gula darah dilakukan tiap minggu sehingga hasil penelitian dapat dipengaruhi oleh salah satu faktor yaitu kontrol terkait dengan pola makan responden selama masa treatment masih belum optimal. Saran untuk penelitian selanjutnya yaitu gunakan manajemen pemantauan yang lebih baik untuk menghindari adanya bias dan penambahan jumlah sampel untuk penelitian selanjutnya.

\section{REFERENSI}

Adika dkk. (2013). Diabetes Mellitus. Pustaka Muslim (40).

Karim, N., Jeenduang, N. \& Tangpong, J. (2018). Anti-Glycemic and AntiHepatotoxic Effects of Mangosteen Vinegar Rind from Garcinia mangostana Against HFD/STZ-Induced Type II Diabetes in Mice. Polish Journal of Food and Nutrition Sciences, 68 (2), 163-169.

Khotimah, H.,Winarsih, S. dan Arif, MN.. (2010). Potensi Ekstrak Metanol Kulit Manggis (Garcinia mangosta L.) Terhadap Kondisi Glukosa Tinggi. Skripsi. Semarang. UNBRA.
Manukumar, HM et al. (2017). Evidences for diabetes and insulin mimetic activity of medicinal plants: Present status and future prospects. Critical Reviews in Food Science and Nutrition 57(12): 2712-2729.

Marewa, LW. (2015). Kencing Manis (Diabetes Mellitus) di Sulawesi Selatan.1nd ed. Jakarta: Yayasan Pustaka Obor Indonesia

Pedraza-Chaverri, J. (2008). Medicinal properties of mangosteen (Garcinia mangostana). Food and Chemical Toxicology, 46 (10), 3227-3239. Available at: http://dx.doi.org/ 10.1016/j.fct.2008.07.024.

Riyadi, Sujono S. (2008). Keperawatan Pada Pasien dengan Gangguan Eksokrin dan Endokrin pada Pankreas, Graha Ilmu. Yogyakarta.

Ryu, H.W. et al. (2011). $\alpha$-Glucosidase inhibition and antihyperglycemic activity of prenylated xanthones from Garcinia mangostana. Phytochemistry, 72 (17), 2148-2154. Available at: http://dx.doi.org/10.1016/j.phytochem.20 11.08.007.

Sarmoko. (2018). Sulfonilurea, Golongan Obat Diabetes yang Sering Diresepkan Bagi Pasien. Hello sehat Group. Available at: https:// hellosehat.com/hidup-sehat/tipssehat/obat-diabetes-golongan sulfonilurea/. Accesssed on 4 January 2019.

Manurung, R.S dkk. (2013). Efek Antihiperglikemia dari Estrak Kulit Buah Manggis Terhadap Pasien Diabetes Mellitus. UNSRAT MANADO.

Hartini, Sri. (2009). Diabetes? siapa takut!! Panduan Lengkap untuk Diabetesi, Keluarganya, dan Profesional Medis, Bandung : PT. Mizan Pustaka.

Umar. (2015). Khasiat Fantastis Kulit Manggis, Jakarta: Grasindo.

Warisno. (2012). Kulit Manggis: Hidup Sehat Berkat Ratu yang Berkhasita. Jakarta: PT. Gramedia Pustaka Utama.

World Health Organization. (2017). Diabetes Programme: Country and regional data on diabetes, Available at: https://www.who.int/diabetes/facts/world _figures/en/index 5.html. Accessed on 2 January 2019. 
Nurul Laili, dkk, Pengaruh Pemberian Ekstrak Garcinia Mangostana terhadap Kadar Gula Darah pada Penderita Diabetes Mellitus di Desa Satrean Maron Probolinggo

Yatman, E. (2012). Kulit Buah Manggis Mengandung Xanton yang Berkhasiat Tinggi. Universitas Boorobudur. 324.

Yunitasari, Liska. (2011). Gempur 41 Penyakit dengan Buah Manggis Khasiat dan Cara Pengolahanya untuk Pengobatan. Yogyakarta: Pustaka Baru Pres. 